\title{
Pontes de Tábuas: uma fazenda desgovernada em 1850
}

José Roberto Pinto de Góes

No dia 13 de fevereiro de 1850, escravos da fazenda Ponte de Tábuas, que andavam fugidos há mais de um mês, mataram um ferreiro que residia na propriedade. Notificado do crime, o subdelegado da vila de Nova Friburgo, no Rio de Janeiro, abriu uma investigação e deu início à confecção dos autos de um processo criminal, hoje sob a guarda do Arquivo Nacional do Rio de Janeiro. ${ }^{1}$ Os autos (o processo possui 138 folhas) contam uma história de horror, mas ao mesmo tempo muito humana. Nenhum estado ou experiência parece faltar na descrição que o processo faz do cotidiano da fazenda: medo, esperança, inveja, preconceito, desejo sexual, traição, paixão, ódio, amor, Deus e o diabo. O escrivão foi anotando tudo. Do jeito dele, claro, mas até isso ajuda a imaginar aquela época.

O que o leitor tem diante de si é o acompanhamento cronológico dos procedimentos judiciais, depoimentos, documentos e atas relativos à morte do ferreiro. Busco descrever o desenrolar da investigação e comento os detalhes que me chamam mais a atenção. Para resumir a história, antes de passar a comentar os autos: a fazenda Ponte de Tábuas, pertencente ao comendador Boaventura Ferreira Maciel (que lá não residia - acho que nem botava o pé), era administrada por uma pessoa, digamos, muito pouco iluminada. João Antônio da Silva Ferreira maltratava muito os escravos, não tinha limites, matava. Os escravos fugiram no dia $1^{\circ}$ de janeiro de 1850 . Um mês e meio depois, numa noite chuvosa e sem lua, mataram o ferreiro.

Os quatro primeiros autos são do dia seguinte ao assassinato: a denúncia da morte ao subdelegado de polícia e os exames de corpo de delito no finado e nos dois feridos, o liberto Luís Ventura Dias e Francisco Antônio Ferreira da Silva, sobrinho de João Antônio, o administrador. Entre os dias 18 e 25 de fevereiro, foram ouvidos seis escravos, dois homens livres e o forro Luís.

O primeiro foi o português Francisco Carvalho, morador da fazenda, que se encontrava preso. No seu depoimento fica claro o clima de ódio 
instalado na Ponte de Tábuas, nos dias que antecederam a fuga. Três escravos já haviam estado no terreiro do sítio onde ele morava, denominado no processo de sítio onde morara Domingos sapateiro, ameaçando-o de morte. Andavam armados com porretes. Carvalho disse que 19 escravos tinham fugido. Ele foi levado preso junto com os escravos e só soube da tragédia na cadeia. Devia ser um indivíduo bem pobre, a julgar pelo tratamento que lhe foi dispensado.

Logo no início do processo, uma característica importante da sociedade brasileira daquela época já se deixa revelar. O Carvalho parece saído de gravura de Debret que retrata a situação das pessoas livres, mas pobres, na sociedade escravocrata brasileira. Escravos e pessoas livres pobres viviam juntos, trabalhavam juntos e muitas vezes eram tratados do mesmo jeito por quem tinha alguma autoridade. Não é de admirar que quando não estavam a desejar a morte uns dos outros, como acontecia na Ponte de Tábuas, às vezes formassem famílias.

É o que tem demonstrado estudos recentes, como o de Cacilda Machado, que analisou listas nominativas e registros eclesiásticos do vilarejo de São José dos Pinhais, datados da virada do século XVIII para o XIX. A localidade era vizinha de Curitiba, que, à época, pertencia à capitania de São Paulo. Lá, pessoas pobres, mas livres, às vezes se casavam com escravos. Como Machado comparou fontes diversas nas quais os casais foram registrados, pôde constatar que a situação jurídica dessas pessoas (quando anotadas) podia mudar sem maiores explicações. Por exemplo. Em 1766, Isidoro e Mariana se casaram. Está anotado no livro da igreja. Ele era, aparentemente, uma pessoa livre, pois do registro não consta que fosse forro nem escravo. Ela era escrava de Nazário Ferreira. Pela lista nominativa de 1765, sabe-se que Isidoro (então com 40 anos) era agregado no domicílio de $\mathrm{Na}$ zário, o dono da sua esposa. Tiveram ao menos uma filha, Júlia, que morreu com seis meses de idade. No registro de óbito da criança, de 1772, Machado descobriu que Mariana era parda. E que ambos os pais eram tidos por escravos do tal Nazário. Como Isidoro foi também qualificado de administrado, tudo indica que se tratava de um indivíduo de origem indígena. Esses "brasileiros" talvez formassem a parte mais pobre do Brasil. Nestas circunstâncias, não espanta que não restasse claro se ele era livre ou escravo.

Provavelmente, isso não tinha muita importância no dia-a-dia de Isidoro, agregado no domicílio do senhor da sua esposa. Talvez a condição 
de agregado testemunhe mais da vida dele e daquela sociedade do que a sua formal condição jurídica. Nazário tinha oito escravos, não era nenhum fazendeiro abastado e importante. Mas tinha a sua própria (e modesta) clientela, da qual Isidoro fazia parte. ${ }^{2}$ Quanto mais gente se agregasse sob o seu poder, de mais respeito se fazia credor, claro. E o que Isidoro recebia em troca, além da obrigação de dar algum trabalho, obediência e lealdade? O amparo possível. Um lugar para morar, meios para subsistir e até uma mulher. Como ressaltou Cacilda Machado, ao ler o registro do óbito de Isidoro, após a sua morte não foi aberto nenhum inventário, já que bens ele não possuía - mas teve missa de corpo presente e foi sepultado na Igreja Matriz. ${ }^{3}$

O próximo a ser inquirido foi o escravo Narciso, de nação Moçambique. Narciso é um caso muito curioso. Pela leitura dos autos, não fica clara a sua participação no episódio, nem o seu lugar naquele grupo de escravos. Ele mentiu e disse que na noite da morte do ferreiro foi trancado pelo feitor escravo Pedro Cabinda. E que não ouviu nada, pois “a roda do moinho que fica ao pé do seu quarto, e que nessa noite trabalhava, não deixava ouvir nada”. É uma boa frase, pois remete às relações entre humanidade e trabalho e depõe acerca do tema numa sociedade escravocrata. A rigor, a roda é posta para funcionar pela engenhosidade e trabalho humanos, ela não trabalha, é uma coisa. Juridicamente, o escravo é uma propriedade de alguém, portanto, uma coisa, mas trabalha, e muito. Mas o que rezava a lei tinha que se dobrar à humanidade do cativo. Ele era tão inteligente, astucioso e "arteiro" quanto o seu senhor.

Nesse primeiro interrogatório, Narciso atribuiu a fuga ao medo que os escravos tinham do administrador João Antônio e revelou as atrocidades que ocorriam na fazenda. Contou do duplo homicídio dos escravos Basílio e Inês e deu detalhes sobre os antecedentes imediatos da fuga. Poucos dias antes, Antônio Pernambuco apareceu na roça onde os escravos trabalhavam e concitou-os à fuga: "Meus parceiros, vamos fugir, porque o senhor João Antônio quer dar cabo de nós todos." Disse isso e mostrou um braço inchado por pancadas que recebera do administrador. $\mathrm{O}$ feitor Pedro e os demais, no entanto, houveram por bem esperar um pouco mais, ter "mais um bocado de paciência". Um bocado mais de paciência é uma idéia tão interessante quanto a roda que trabalha, no que diz 
respeito à natureza da escravidão. Os escravos eram, antes de tudo, escravos da própria paciência - da mesma forma como se é, hoje em dia, aliás. Mas não se diga que a paciência é sempre erro, não é. Ao contrário: paciência é quase sempre inteligência. João Antônio não tinha nenhuma e só causou sofrimento e prejuízo econômico.

Graças ao depoimento de Narciso sabemos como se precipitou a crise que teve por desfecho a fuga. Tudo começou, claro, com a truculência do administrador, daquela vez voltada contra uma criança. João Antônio a jogou ao chão e deu-lhe pancadas. A preta Apolônia contou ao pai, o escravo Rafael, que ficou "muito sentido" e queixoso. Nessa ocasião o nome da escrava Maria do Rosário aparece pela primeira vez no processo. Segundo Narciso, ela contou ao administrador que Rafael estava inconformado. Sabendo disso, e temendo pelo que João Antônio viesse a cometer, dezenove cativos, incluindo Rafael, perderam a paciência e abandonaram a sede da fazenda, fixando-se em suas matas.

No interrogatório também aparecem detalhes sobre as horas que antecederam o assassinato do ferreiro. Na tarde do dia 13 de fevereiro, o liberto Luís e o feitor e sobrinho Francisco, indo tratar de uma porca, toparam com o escravo fugido Cabungu. Tentaram alcançá-lo, mas Cabungú correu mais. Informado que os escravos estavam nas proximidades, João Antônio organizou um grupo para fazer uma ronda na fazenda. Já anoitecera quando Pedro Cabinda, Francisco (feitor e sobrinho do administrador), o ferreiro Manoel e o "crioulo" Luiz saíram em busca dos escravos. Tinha mais gente nessa ronda, pelo que revelam os autos seguintes.

Narciso disse ainda que, na noite do crime, além de estar trancado, estava doente. Num interrogatório que respondeu quase dois meses depois, dessa vez na condição de "testemunha informante", acrescentou que se não estivesse doente também fugiria.

$\mathrm{O}$ auto seguinte traz o interrogatório feito ao escravo Miguel Congo. Ele era outro que se conservara na sede da fazenda. Desde a fuga, dormia "fechado". Pelo que disse, havia uma senzala na fazenda que abrigava uma "gente" e que podia ser trancada. Seria um barracão de alvenaria, com uma só entrada, janelas gradeadas e guardado por um portão de ferro, como recomendavam alguns escritores escravistas daquela época? ${ }^{4}$ Não, não era, como não deviam ser assim a maior parte das senzalas, das habitações, 
das casas dos escravos. De qualquer modo, tanto faz se a senzala era de alvenaria ou uma casa de pau-a-pique, como a retratada por Rugendas, nenhuma das duas podia impedir o escravo de fugir, se assim ele quisesse. ${ }^{5}$

Miguel disse que só soube das altercações no dia seguinte, pelo "preto Luiz forro". Essa é a única menção, em todo o processo, à condição de liberto do "preto Luís". Geralmente, ele é referido à condição de crioulo, isto é, escravo nascido no Brasil, ou à cor da pele preta. O que significa isso? Que os libertos viviam feito escravos, e, portanto, qualificá-los assim era algo irrelevante? Havia alguma verdade nisso, a julgar pelo tratamento dado aos pobres em geral. Mas, pelo que tenho lido em cartas de alforria, a irrelevância de qualificá-lo como liberto estava também na grande quantidade deles no Brasil daquela época. ${ }^{6}$ Eram tantos, que, não fosse esse depoimento de Miguel, não saberíamos que o "preto Luis" era um deles. O “preto Miguel” disse que o administrador matara Basílio crioulo por ciúme que tinha da vítima, por causa de Maria do Rosário.

$\mathrm{O}$ feitor Pedro Cabinda foi o próximo a ser interrogado. Contou detalhes da ronda do dia 13 de fevereiro, em busca dos escravos fugidos. João Antônio formou dois grupos, um que ia para as bandas do sítio "onde morou Domingos sapateiro", e onde então morava Francisco Carvalho, e outro que rumaria para os lados do moinho da fazenda. Do primeiro, faziam parte ele, Pedro, "o crioulo Luiz," o feitor Francisco Antônio e "o preto Moisés”. No caminho, ouviram gritos vindos da direção do moinho. Acharam que João Antônio encontrara os fugitivos e os estava prendendo. Mas quando ouviram gritos de "mata, mata" tiveram medo e fugiram, os escravos no encalço deles. Pedro se escondeu atrás de uma penca de samambaia. Quando o barulho cessou, voltou para a casa, onde passou a noite na companhia do administrador.

Perguntaram a ele se naquela noite havia fechado os escravos antes ou depois do assassinato e ele disse que depois. E deu detalhes: fora, por ordem de João Antônio, acompanhado por “um outro moço", fechar os parceiros na senzala. Exceto Narciso, pois este "costumava dormir sempre solto". Pedro devia estar falando a verdade, pois se os escravos eram fechados, desde a fuga, às 22 horas, como afirmou Miguel, por volta das 20 (hora da morte, segundo Antônio Pernambuco, Silvestre e Valentim) ainda haviam de estar "abertos". Narciso foi trazido e acareado com Pedro. Con- 
fessou que mentira, mas que não tinha ouvido nem participado do barulho. Por que Narciso dormia sempre solto? E se dormia sempre solto, por que foi tão loquaz e detalhista em contar as misérias de João Antônio?

O próximo a ser interrogado foi Luís, o liberto. O título do auto é "Interrogatório feito ao crioulo Luiz Ventura Dias". Ele tinha 21 anos, era solteiro e carpinteiro. Era morador da fazenda, como o português Francisco Carvalho. Contou mais uma vez a história da porca e do encontro com Cabungu. Quanto à ronda, disse que João Antônio organizara dois grupos. $\mathrm{O}$ que ia para o lado do sítio onde morou Domingos era formado por ele, o feitor Francisco e os escravos Pedro e Moisés. Do que se dirigiu para o moinho faziam parte o próprio administrador, o ferreiro Manoel e Narciso.

Tudo indica que os escravos fugidos não o tinham em boa conta, para dizer o mínimo. Tentaram matá-lo com golpes de foice e pancadas. O primeiro teria sido Dionísio. O seguinte, Antônio "repolho". Depois, Antônio Pernambuco. Luís conseguiu fugir atirando-se a um rio. Já estava na casa quando ouviu os gritos do feitor Pedro perguntando se podiam, ele e Moisés, se aproximar. Perguntado se o administrador era "muito rigoroso" com os escravos, respondeu que "não era dos piores, mas que castigava sempre quando havia necessidade". Quem pode dizer que mentia? Sabe-se lá quantos feitores ele conheceu. Mas fato é que, naquele contexto, contemporizar com o administrador não era coisa que interessasse aos escravos. Se ele agia assim no dia-a-dia, explica-se a raiva que despertava nos cativos.

Os libertos eram sempre aliados dos senhores? Em importantes sentidos, eram sim. A própria existência deles, o quão numerosos eram, contribuía para manter acesa a expectativa de liberdade nos demais, o que facilitava o controle senhorial. Além disso, uma vez libertos, esperava-se que se comportassem com gratidão e aprovação. Não poucos levavam isso tão adiante que se tornavam eles mesmo senhores de escravos. Os estudos de caráter demográfico têm apresentado números surpreendentes sobre isso, no Brasil. ${ }^{7}$ Sociedade pautada nas regras e na lógica do Antigo Regime, naturalmente os libertos haviam de ocupar um nicho próprio numa complicada, senão barroca, hierarquia que a todos e a qualquer um reservava um lugar. Inclusive entre os escravos. Antônio Pernambuco não dirá, talvez não sem uma ponta de orgulho, que fora o "primeiro", o principal escravo da fazenda? E a condição de mulato não tinha lá a sua importância? 
Os libertos haviam de ser objeto de inveja (e muitas vezes de raiva) dos escravos, é verdade. Mas isso é apenas um aspecto do problema. Os libertos também eram parentes, muitas vezes. É o que se depreende quando se estudam séries de cartas de alforrias, conservadas em nossos arquivos. Lendo-as, a impressão que fica é que mais um tipo importante de família pode ser acrescentada àquela imaginada por Gilberto Freyre: enorme, inclusiva, patriarcal, chefiada pelo senhor, e à remediada, meio pobre, chefiada por mulheres, apontada por estudos importantes. Ao menos no Rio de Janeiro do século XIX, devia haver muitas famílias composta por pessoas livres, libertos e escravos - e de indivíduos de tudo quanto é cor. ${ }^{8}$ Amor, ódio, família... nada há de novo sobre a terra, Salomão era só sabedoria. Luís disse também que a morte de Basílio havia acontecido antes de ele vir morar na Ponte de Tábuas e que Inês morrera de uma "moléstia de garganta, estando já sã das surras que tinha levado". Acho que ele estava mentindo, mas não saberia dizer sobre suas razões.

A seguir, Luís foi acareado com Narciso, que sustentou haver se conservado aquela noite inteira dentro do seu quarto. Luís sustentou a sua versão e acrescentou que o próprio João Antônio o informara que mandara Narciso e o ferreiro para as bandas do moinho. Ele voltou a negar e disse que se ordens haviam sido dadas ele não as recebera.

$\mathrm{O}$ interrogatório seguinte foi o da africana Genoveva. Disse que na noite do crime estava fechada no paiol, onde sempre o feitor a fechava com os demais parceiros. Como se vê, na Ponte de Tábuas, o paiol, onde se debulhava o milho, e os escravos vez ou outra eram surrados, fazia as vezes de senzala. Ela contou que naquela noite ouvira os gritos do tumulto. Inquirida sobre se Narciso também dormira fechado, disse que não, pois ele dormia só, "em sua senzala", mas que ignorava se ele havia integrado a ronda na ocasião. Não sabia por que os escravos haviam fugido. Sobre as mortes de Basílio e Inês, disse, do primeiro, que João Antônio o achou com um furto, meteu-o no tronco, castigou-o com o chicote e lhe deu cutiladas com um facão, do que o escravo morreu. Sobre Inês, disse que, por ela ter fugido certa vez, o administrador a castigou dois dias com "chicote e bacalhau"; que depois a parceira começou a queixar-se da garganta e em poucos dias faleceu. 
É bem possível que ninguém, na Ponte de Tábuas, tenha deixado de escutar os gritos, que não foram poucos, naquela noite escura e sem lua em que o ferreiro Manoel perdeu a vida.

O auto seguinte traz o depoimento da escrava Maria do Rosário. Ela afirmou que na hora do crime estava em casa e contou que, em torno da Ave-Maria, isto é, à hora do crepúsculo, os grupos formados pelo administrador para fazer a ronda na fazenda já estavam prontos. Nessa ocasião, o ferreiro teria se apresentado a João Antônio e dito que já "eram horas". João Antônio se preparara para sair, mas fora impedido pelo choro de uma "crioulinha" adoecida. Mandou que os outros seguissem na frente, enquanto providenciava assistência à criança. Mas não teve sequer tempo de sair da casa, pois, logo depois, adentrou à mesma, todo ensangüentado, o sobrinho e feitor Francisco. Contou também que da casa era possível ouvir os gritos que acompanhavam a luta.

O depoimento de Maria do Rosário sobre as mortes dos escravos é ambíguo. Disse que Basílio morrera das pancadas que lhe dera o administrador, mas acrescentou que falecera duas semanas após a surra, tempo em que nada comeu. Não é possível saber se ela está contando uma versão suicida para o destino de Basílio. Até porque, a essa altura, o escrivão já devia estar convencido da truculência de João Antônio e bem pode ter, mesmo involuntariamente, escrito o testemunho dela de forma a dizer que Basílio morrera por causa das pancadas do administrador. Sobre Inês, ela contou que fora castigada por fugir e, depois, queixando-se de uma dor na garganta, morrera. Mais uma vez fica difícil saber se a culpa era ou não de João Antônio. De qualquer forma, ela asseverou que não sabia o motivo da fuga e que o administrador tratava bem os escravos da fazenda.

Depois foi a vez de Moisés ser ouvido. Contou que estava fora da fazenda havia três anos e que só tinha voltado depois da fuga, a mando do comendador Boaventura, com ordem de encontrá-los e convencê-los a tomarem padrinho, de modo a retornarem pacificamente à fazenda. Por isso, não podia dizer dos motivos dos escravos para fugir. Acrescentou novos detalhes sobre a noite do crime. Disse que ele, o "crioulo" Luiz e o feitor Francisco, que seguiam em direção ao sítio onde morara Domingos sapateiro, ao ouvirem gritos para o lado do moinho, para lá se dirigiram, sendo então atacados pelos escravos fugidos. E que enquanto Luís e o feitor eram 
alvos de cutiladas, "o pardo" Pernambuco gritava "que matassem”, enquanto Silvestre gritava que não matassem, que "dessem só para ensinar".

$\mathrm{O}$ último desses primeiros depoimentos foi o do açoriano e sitiante Antônio Francisco d'Tevez, provavelmente morador das redondezas. O seu testemunho mostra a situação de desgoverno e ódio em que se encontrava a Ponte de Tábuas naqueles dias. Contou que, indo à fazenda para escolher uns novilhos, João Antônio o mandara falar com Francisco Carvalho, o lavrador que morava no sítio em que morara Domingos sapateiro. Lá chegando, este lhe disse que não era possível recolher o gado, pois não havia mais escravos para fazê-lo, fugidos que estavam. E acrescentou que João Antônio que se precavesse, pois, sendo aqueles escravos "muito maus e de má indole", eram bem capazes de "fazer-lhe alguma".

Todos esses depoimentos foram tomados entre os dias 18 e 25 de fevereiro. $\mathrm{O}$ auto seguinte data do dia 20 março e contém uma petição do procurador de Boaventura na qual solicitava que os escravos Narciso e Miguel, que ainda se encontravam presos, fossem devolvidos à fazenda. A justiça entendeu que o procurador tinha razão e os mandou soltar.

Os próximos interrogatórios foram feitos entre os dias 10 e 15 de abril e os respondentes eram os três escravos mais implicados na fuga e na morte do ferreiro: Antônio Pernambuco, Valentim Moçambique e Silvestre crioulo.

O primeiro foi Pernambuco, solteiro, trabalhador de roça, filho de Manoel Bento e Luzia. Seguindo a fórmula costumeira, o escrivão anotou que ele estava ali "livre de ferros e de nenhuma outra opressão". Estava na fazenda havia quatro anos, desde que viera de Praia Grande. Provavelmente, a referência é a Vila Real de Praia Grande, o nome de Niterói até 1835. Possivelmente o povo ainda chamava Niterói de Praia Grande, 15 anos após a lei mudar o nome do lugar. Não viera diretamente de Pernambuco para Friburgo. Já tinha muita estrada, aos 28 anos.

Foi perguntado sobre o motivo da fuga e responsabilizou a truculência com a qual João Antônio tratava os escravos. Disse que assistiu ao administrador matar Basílio com cutiladas na cabeça e uma facada nas costas. Contou que todos viviam "cheios de terror". Perguntado por que eles, em vez de fugir, não foram ter com Boaventura, que morava na cidade, ou mesmo com pessoas "amigas deles", na vila de Nova Friburgo, para contar dos "rigores" com que eram tratados, respondeu que não procederam assim por medo. 
Essa parte do depoimento de Antônio Pernambuco lembra as palavras de Joaquim Nabuco, segundo as quais a autoridade senhorial dependia da capacidade do dono de inspirar o horror no espírito dos escravos. ${ }^{9}$ De fato, sem o recurso ao medo ninguém governava uma fazenda tocada por escravos. Mas era próprio da sabedoria do tempo que os castigos haviam de ser medidos e proporcionais às culpas. Todos os letrados que escreveram sobre o assunto chamaram a atenção para isso e, como se vê pelo que se passava na Ponte de Tábuas, tinham razão. ${ }^{10}$ João Antônio era um desastre. Para os escravos e para o proprietário deles, que era roubado em gente, animais e lucros. $\mathrm{O}$ medo bem dosado conservava a vida no lugar e não era apenas atributo do senhor. Do medo do senhor ante a raiva dos escravos dependia também uma exploração econômica dosada, que fazia a vida em cativeiro menos intolerável. O problema ali era que o comendador não vivia na fazenda e, provavelmente, desastrado no zelo de seus próprios interesses, parecia ignorar o que se passava no seu feudo.

Chama a atenção também a pergunta sobre por que os escravos não procuraram pessoas "amigas" na vila que pudessem interceder por eles, talvez colocando Boaventura a par das atrocidades cometidas pelo administrador. Ou chamando a polícia. $\mathrm{O}$ contato dos escravos com parcelas da população livre era freqüente, muito mais do que uma idéia caricatural da escravidão pode conceber. Nas alforrias registradas em cartórios do Rio de Janeiro, daquela época, existem muitos casos de pessoas socialmente mais bem situadas ajudando os escravos a pagar por sua liberdade. Por isso as muitas famílias brasileiras que reuniam livres, libertos e escravos, como as comentadas acima.

Fato é que a fuga não tinha como não chegar aos ouvidos do comendador. Antônio Pernambuco disse que só voltou a ter contato com as pessoas da casa quando encontrou, no mato, o escravo Moisés, que a mando de Boaventura os estava procurando havia cerca de oito dias. Entre o dia da morte, 13 de fevereiro, e a volta dos escravos, 25 de março, passaram-se 15 dias. Na primeira semana, Moisés deve ter ficado à disposição da justiça, por assim dizer. Boaventura o mandou achar os escravos e convencê-los a voltar, ainda no tempo em que a Ponte de Tábuas vivia sob o desgoverno de João Antônio. E este impediu que Moisés cumprisse as ordens do senhor e fosse reunir o seu povo. A escravidão é bíblica, muitas vezes. 
Pernambuco disse que nos quase três meses que durou a fuga nunca tiveram contato com gente da casa, que de noite iam às roças da fazenda e colhiam milho e abóboras, e era disso que se alimentavam.

A versão contada por Pernambuco sobre a noite do assassinato é inverossímil, ao menos na parte em que afirma que quando apareceu um vulto, e eles escutaram uma arma sendo engatilhada, todos se puseram em fuga. Assim não sobraria ninguém para matar o ferreiro. De qualquer forma, ele disse que a sua consciência de nada lhe acusava e não sabia por que estava preso - desde que um alferes, comandando um destacamento, foi buscá-lo na fazenda, na senzala, onde dormia "fechado" desde que a casa retornara.

Um momento riquíssimo do auto desse interrogatório de Pernambuco tem início quando, a pedido do seu curador, foi-lhe perguntado quanto tempo estivera "em ferros". Ele respondeu que por quatro meses. $\mathrm{O}$ curador procurava chamar a atenção para a truculência do administrador, certamente. A seguir ele foi perguntado sobre se havia sido feitor. Disse que sim, que fora nomeado por João Antônio quando viera de Praia Grande e que fora feitor na fazenda até o administrador colocá-lo "em ferros" pelos já revelados longos quatro meses. Isso fazia uns quatro anos. Disse que naquela época merecia a confiança de João Antônio e que seus parceiros o obedeciam e sempre faziam o que ele mandava. E acrescentou: "sempre o obedeceram e o respeitavam como primeiro escravo da fazenda e com alguma superioridade a eles."

Quanto deste acréscimo pertence à justiça, por intermédio do escrivão, e quanto é do próprio Pernambuco? Acho que é de ambos. Falavam o mesmo idioma da obediência que devia regular a relação entre superiores e inferiores. Com certa afetação de orgulho, aliás. Talvez se o comendador tivesse entregado a fazenda nas mãos do mulato pernambucano a sua empresa não teria tantos prejuízos. Ele por certo sabia como mandar nos escravos. Tanto é que mentiu, ou se equivocou, a respeito do julgamento que os demais faziam dele. Pois, com a exceção do compadre Silvestre, quase todo mundo deu um jeito de incriminá-lo. Mas nesse interrogatório ele disse que os parceiros, mesmo depois de destituído do posto de feitor, e "em ferros", continuaram estimando-o e obedecendo-lhe como antes.

Quando perguntaram se no mato também era assim, respondeu que continuava a merecer a confiança dos parceiros, mas que lá “cada um governava a sua pessoa". 
O próximo a ser inquirido foi Silvestre crioulo, filho de Joaquim cigano e Maria Joaquina, nascido em Maricá. Maricá localiza-se nas redondezas de Praia Grande e é possível que ele e Pernambuco já se conhecessem antes de chegarem à fazenda Ponte de Tábuas. Eram compadres, eram parentes por escolha. Silvestre tinha uns 25 anos e estava na fazenda havia seis. Pernambuco tinha 28 e estava na fazenda havia oito. $\mathrm{O}$ compadrio revela que ao menos um dos dois era casado. Casado sem papel passado pela Igreja Católica, pois ambos se disseram solteiros. Isso era o mais comum na população escrava (e também não era raro na população livre mais pobre ${ }^{11}$ ).

Silvestre apontou o mesmo motivo para a fuga, "os maus tratamentos", e também disse que não tiveram contato com as pessoas da casa desde que fugiram, que se alimentavam de milho e abóboras.

Até que ponto Silvestre podia conservar a lealdade para com o compadre? O seu depoimento de alguma forma conserva o conflito que vivia. Perguntado se alguém aconselhara a fuga, respondeu que quem tomou a iniciativa foi Antônio Pernambuco, mas que todos os demais, "espontaneamente", a ele se uniram.

Sobre a noite do crime, contou que, como não suportavam mais a chuva e a fome, decidiram-se a voltar e "tomar padrinho", nem que fosse com o próprio João Antônio, com o propósito de retornar à fazenda. Tomar padrinho era o costume da época, algum homem livre devia assumir a figura de protetor do escravo, de porta-voz. Eles deviam se conservar mudos, de certa forma. A escravidão era cheia de ficções jurídicas e essa era uma delas, que tornava a condição de escravo equivalente à de menores. Era uma ficção, pois mesmo a fórmula virando costume não alterou a natureza das coisas, pois todo mundo continuou a falar por palavras, escolhas e atos.

O relato do episódio no qual morreu o ferreiro também é muito interessante. Ele disse que quando chegaram ao moinho da fazenda, um vulto, "que ele supóe que era branco pela maneira de falar", dirigiu-se a eles e, por duas vezes, perguntou quem estava lá. De 1850 é a lei Euzébio de Queirós, que aboliu finalmente o tráfico transatlântico de pessoas. Dos oito escravos do comendador de procedência conhecida, seis eram africanos e apenas dois eram crioulos. Dos africanos, metade era Moçambique. Os escravos da África Oriental tornaram-se importantes na importação de africanos após a Inglaterra apertar o cerco sobre a circulação de negreiros na costa 
Ocidental, sobretudo na região do golfo da Mina. É possível que a maior parte dos escravos da fazenda fosse africana e que predominassem os Moçambiques. Enfim, a língua portuguesa não era coisa de preto, aqui tornado sinônimo de escravo, que eram principalmente africanos e tinham suas próprias línguas. Fica sem resposta o modo como falava o crioulo e mulato Pernambuco, ou o crioulo preto e liberto Luís. No caso de Silvestre, parece que o fato de ter nascido no Brasil não o livrava de certo estranhamento com a língua de branco. Mas essa pode ser uma conclusão apressada, pois pode ser também que ele associasse branco a português de nascimento: pelo menos três pessoas que aparecem no processo são portuguesas, inclusive o sobrinho do administrador, que devia ser também.

Silvestre admitiu que o autor da primeira foiçada no ferreiro foi o compadre Pernambuco e disse que, logo após, ele e Valentim puseram-se a bater no ferreiro, mas não sabia se já então o infeliz estava morto. Fugindo do local, e topando com Luís e Francisco, do primeiro ocupou-se Antônio Pernambuco e, do segundo, os demais. Depois, ficaram no mato até serem encontrados por Moisés, que trazia ordens do procurador de Boaventura para retornarem à fazenda, que já não se achava sob o domínio de João Antônio.

No fim, acrescentou (não fica claro se foi perguntado) que todos deram as foiçadas movidos pelo exemplo de Pernambuco, "porque se aquele o não fizesse, nem ele nem seus companheiros seriam capazes de o fazer".

$\mathrm{O}$ interrogatório seguinte foi o de Valentim Moçambique, que não sabia o nome dos pais porque chegara ao Brasil muito jovem, "por ter vindo muito pequeno de sua terra”, como anotou o escrivão. Tinha já cerca de 40 anos, segundo a opinião do doutor e do farmacêutico que o examinaram. Era solteiro (mas podia ser casado do jeito que se casava a maior parte) e trabalhador de roça. Morava no sítio que fora de Domingos sapateiro, até que João Antônio decidira que ele passaria a trabalhar na fazenda, de onde fugiu. No auto que traz o depoimento do morador do sítio àquela altura, Francisco Carvalho, há um relato confuso sobre escravos de lá que diziam que se fossem obrigados a ir para a fazenda, haviam de fugir. Pode ser que Valentim fosse um desses, pode ser que ele estivesse entre aqueles que ameaçaram Carvalho, armados de porretes.

João Antônio já o maltratara muito. Certa vez, por causa de uma vaca que tinha sumido, o administrador o amarrara a um esteio (no paiol?) e o surrara violentamente, inclusive com golpes de faca na cabeça. 
Valentim devia detestar também Antônio Pernambuco, pois assegurou que o mulato obrigara todos a fugir. As coisas teriam se passado assim: Pernambuco os incitou a fugirem, ele e os demais se recusaram, o mulato ameaçou contar a João Antônio que se planejava uma fuga, e eles, "possuidos de terror" pelo que poderia fazer o administrador, deixaram-se conduzir. E acrescentou que, mesmo no mato, "o dito Antônio Pernambuco foi sempre o seu capitão". De fato, para dar um depoimento desse teor, só não se importando nada com o destino do escravo pernambucano. É possível que isso apenas tenha confirmado a convicção do escrivão sobre a maior culpa de Antônio Pernambuco. Afinal, desde o início o mulato era apontado como cabeça da desobediência e primeiro escravo a distribuir foiçadas. Mas o dedo acusador de Valentim pode ter levado o escrivão a cometer um ato falho, no bom sentido psicanalítico. Ele escreveu que, segundo Valentim, Pernambuco "se mostrava bastante zangado contra o administrador, não só por o ter demitido do lugar de feitor, como por castigos que a ele tinha servido, digo, tinha sofrido". Àquela altura devia estar achando que tais castigos haviam sido mesmo servidos, mais dos que sofridos.

Valentim não poupou o parceiro. Disse que, certa vez, no mato, os companheiros mais moços, e logo todos, decidiram voltar. Mas Antônio Pernambuco não deixou, "pondo-se adiante do caminho e ameaçando aquele que se animasse a dar um passo". Na noite em que voltaram, chovia tanto que a vontade de Pernambuco pôde ser dobrada (mas ele se pôs à frente de todos, mais uma vez). Ele, Valentim, trazia uma panela e um cobertor, porque "era o cozinheiro no mato". Atribuiu a morte do ferreiro e as foiçadas em Francisco e em Luís aos compadres Pernambuco e Silvestre. Deu detalhes, colocou palavras na boca de Pernambuco:

daí a pouco, vindo o mesmo Pernambuco unir-se a eles, lhes contou que tinha morto o vulto e que tinha dado umas foiçadas no Luiz, que caiu dentro do rio... tendo eles todos desaprovado ao Pernambuco a morte que dizia ter feito, que este respondeu que o tinha feito porque não queria servir mais nessa terra, e que só queria servir a seu senhor, o comendador Boaventura, e que com aquela já era a terceira morte que tinha feito.

Esse trecho do auto requer muita atenção para ser realmente compreendido e convenientemente apreciado. A intenção de Valentim parece óbvia: jogar toda a culpa nas costas de Pernambuco - que já teria sido o autor de 
três mortes, confessadamente, segundo ele. Mas isso é o que menos importa no que o escrivão anotou do depoimento dele. O que mais ensina sobre aquela sociedade é a frase que Valentim atribui a Pernambuco: que matou "porque não queria servir mais nessa terra, e que só queria servir a seu senhor, o comendador Boaventura". Valentim não tinha nenhum motivo para descrever um Antônio Pernambuco disposto a ser um bom escravo. Mas foi o que fez, e é isso que mais interessa ao leitor do processo criminal.

É claro que Antônio Pernambuco não gostava de ser escravo, mas é muito possível que ele não concebesse outro tipo de mundo senão o fundado nos hábitos e costumes da escravidão. O problema maior, no julgamento dele, segundo deu a entender Valentim, involuntariamente, não era a escravidão em si, mas a maneira como era administrada na fazenda. Pernambuco não estava disposto a "servir mais nessa terra", a Ponte de Tábuas, e fazia muito bem. Mas concordava em servir ao comendador, na cidade, e até queria. Como Moisés, que para lá fugira havia tempos.

Os eventos relatados nos autos precedem a lei Euzébio de Queirós. Em 1850, a escravidão era algo ainda profundamente enraizado no Brasil. Joaquim Nabuco falava da grande força moral que a instituição tinha no país e atribuía o fato à peculiaridade brasileira de possuir um mercado de escravos freqüentado por todo tipo de indivíduo. Nas palavras dele: "A escravidão entre nós manteve-se aberta e estendeu os seus privilégios a todos indistintamente: brancos ou pretos, ingênuos ou libertos, escravos mesmos, estrangeiros ou nacionais, ricos ou pobres." 12 Estudos mais recentes, de caráter demográfico, têm corroborado as palavras do escritor, tribuno e figura maior do abolicionismo brasileiro. O já citado estudo de Luna e Klein mostra a expressiva participação da população livre, de cor preta e parda, no grupo de senhores de escravos. ${ }^{13}$ Portanto, não eram poucos os brasileiros, de tudo quanto é cor e procedência, comprometidos com a escravidão. Esse quadro só começou a mudar quando a Inglaterra impôs ao Império do Brasil o fim do tráfico transatlântico, ${ }^{14}$ o que elevou o preço do escravo e tornou a sua aquisição proibitiva aos indivíduos de menor poder aquisitivo. ${ }^{15}$ A mão-de-obra escrava foi então migrando para a mão dos fazendeiros mais ricos do Sudeste do Brasil, permitindo que sucessivos grupos sociais desfizessem seus laços com a escravidão. Mas isso levou quase a segunda metade do século XIX inteira. Não foi por outro motivo, 
senão a grande disseminação e força moral da escravidão, que o Brasil foi o último país da América a abolir o trabalho escravo.

Portanto, é perfeitamente compreensível que Antônio Pernambuco tomasse a escravidão como coisa muito natural. Acresce ainda o fato de ele ser um escravo nascido no Brasil, um crioulo. Henry Koster, um inglês que viveu em Pernambuco no início do século XIX, onde se tornou senhor de escravos, achava que os crioulos se tinham por superiores aos africanos, e era tamanha a desconfiança mútua que nenhum dos dois criam possuir uma origem comum. É difícil conhecer as reais opiniōes de crioulos e africanos sobre as diferenças e semelhanças que ora os afastavam, ora os reuniam. A própria idéia de crioulo e africano não deixa de conter certa dose de mistificação, ao reunir tantos indivíduos em categorias tão genéricas e abrangentes. Os escritores daquele tempo, contudo, deixaram escritos alguns julgamentos que permitem saber como a sociedade escravista avaliava ambos. Koster preferia ter a seu serviço africanos já habituados ao cativeiro. Ele achava que os crioulos eram criaturas mais impacientes e explicou-se assim:

Acredita-se geralmente que os negros crioulos e os mulatos aprendem mais depressa um ofício que um africano. Essa aptidão superior de aproveitar o que aprendem é, sem dúvida, devido ao conhecimento desde a infância com a linguagem e maneiras dos amos. Todavia, pela pequena experiência que tive e pelas observações que ouvi de amigos em posição de julgar melhor os escravos que eu próprio, penso que um africano quando se adapta e parece ter esquecido sua primitiva condição, é um servo tão valioso como um crioulo negro ou um mulato. Merece, em geral, mais confiança. Longe de submeter-se humildemente à situação em que nasceram, eles roem o freio da escravidão com impaciência. $\mathrm{O}$ aspecto diário de tantos indivíduos de sua raça que são livres, leva-os a desejar a igualdade e lamentar a cada momento seu infortunado cativeiro. A consideração com que pessoas livres de castas mestiçadas são acolhidas tende a aumentar o descontentamento dos seus irmãos escravos. Os africanos não sentem isso porque são considerados pelos seus irmãos de cor como seres inferiores, e a opinião pública estabeleceu uma linha entre ambos, de tal sorte que o escravo importado crê que o crioulo e ele não têm origem comum. ${ }^{16}$

Embora não sejam raros os casos de africanos libertos, os crioulos, de fato, obtinham com mais facilidade cartas de alforria, sobretudo os do sexo feminino. E, por todos os motivos apontados por Koster, é bem possível que 
fossem mais impacientes mesmo. Mas com a escravidão deles, de cada um, e não com a escravidão como princípio regulador das relações humanas. Como assinalou Nabuco, no Brasil até escravos podiam possuir escravos. ${ }^{17}$

A seguir, os três escravos foram acareados. Silvestre e Valentim sustentaram que Antônio Pernambuco fora o primeiro a dar com uma foice no ferreiro. Pernambuco os contradisse, alegando que todos deram as foiçadas ao mesmo tempo. E acrescentou que a foice de Valentim até se partira, na ocasião, ficando o cabo do instrumento e arma ao pé do morto. Valentim negou e disse que só botou a mão em uma foice após o assassinato, quando já fugiam de volta para o mato. Pernambuco e Silvestre disseram que ele mentia, confirmando este último que a foice que Valentim trazia se quebrara no corpo do ferreiro. Ambos também negaram que o primeiro, no mato, fosse "o capitão ou chefe deles".

No mês de abril ainda seriam ouvidos, agora na condição de testemunha informante, os escravos Pedro Cabinda e Moisés Moçambique, o liberto Luís e o feitor Francisco, quatro lavradores das redondezas e João Antônio. Os escravos, o liberto e o administrador foram também acareados com os três escravos que àquela altura estavam presos: Pernambuco, Silvestre e Valentim.

Pedro Cabinda era solteiro, serrador por ofício, feitor por escolha de João Antônio e tinha cerca de 30 anos. Perguntado se o administrador era "muito áspero" com os escravos, respondeu que sim e acrescentou que já castigara o réu presente, Antônio Pernambuco, ex-feitor, demitido "por ser arteiro".

Pedro disse que não sabia nem "nunca tinha ouvido dizer" por que os escravos haviam fugido. Mas não se escusou a dar detalhes da crueldade do administrador, quando perguntado pelos finados Basílio e Inês. Afirmou que já era feitor na ocasião daquelas mortes e que tudo presenciara. Assistiu a Basílio ser acusado pela falta de um saco de feijão e, de noite, no paiol, à vista de todos, ser preso a um esteio para bem tomar uma surra. Na ocasião, "cheio de raiva", João Antônio lhe dera também cutiladas na cabeça. No dia seguinte, ainda de madrugada, quando foi tirar Basílio do tronco para, por ordem de João Antônio, aplicar outra surra no parceiro, encontrou-o já morto. Sobre Inês, contou que a escrava despertara a ira do administrador por haver fugido. Recapturada por um capitão de mato, João Antônio “a mandou surrar muito". E não ficou só nisso: após a surra, 
mandou que fosse aplicado molho de pimenta em suas feridas. Inês não se recuperaria das atrocidades, permanecera doente e pouco depois faleceu.

Pelo que se entende dessa parte do depoimento, ele encontrou Basílio morto de madrugada, quando ia lhe aplicar mais açoites. Pedro Cabinda era um adulto de 30 anos, africano, feitor. Não fugiu, mas também não denunciou os planos de fuga, apenas recomendou mais paciência. Não parecia gozar da animosidade de ninguém. Mas como podia isso subsistir quando era obrigado a açoitar um "parceiro", de vez em quando?

Antônio Pernambuco era um indivíduo arteiro. Calejado e tido por esperto, devia usar de muita engenhosidade, arte e manha no empenho de estabelecer um limite ao domínio senhorial. Se tivesse um dono igualmente arteiro em reduzi-lo à obediência possível, o jogo, ou a peleja, havia de continuar e hoje não saberíamos que Pernambuco foi um dia o primeiro escravo da fazenda, que João Antônio existiu, que Maria do Rosário parecia estar disposta a muita coisa por uma carta de alforria, que Moisés era pessoa de discernimento, que Narciso tinha a sua própria senzala e por aí vai. Mas João Antônio dá a impressão de haver sido pessoa muito apartada de qualquer arte que não fosse a de se entregar ao lado mais obscuro da alma humana, onde habita tudo quanto Deus proibiu à criatura desde o Antigo Testamento. Resultado: a Pontes de Tábuas virou um vale de lágrimas, antes de não ter mais escravo algum para juntar o gado e entrar em colapso (claro, o administrador foi demitido).

A descrição da noite do assassinato também contém detalhes interessantes. O grupo ao qual Pedro Cabinda se juntou para fazer a ronda, já o sabemos, rumou para o lado do sítio onde morou Domingos sapateiro e mudou de curso quando ouviu gritos vindo do lado do moinho. Pedro contou que, chegando próximo ao local e escutando os gritos de " $m a t a$, mata", ele e seus parceiros julgaram que era o administrador quem gritava, enquanto amarrava alguns dos escravos fugidos. Bem plausível mesmo, tais gritos na boca do administrador. Mas era Antônio Pernambuco quem gritava, segundo disse o feitor-escravo, que lhe reconheceu a voz. Em seguida, escutou o feitor-sobrinho Francisco gritar, por sua vez: "esperem lá, não pensem que eu não hei de ir". E indo, foi cercado pelos cativos fugidos, prontos a cometerem uma segunda morte, naquela noite. Pedro e Moisés, "cheios de terror", foram se esconder no mato até cessar o barulho. 
Ele contou ainda que quando, afinal, pôde ir ter com João Antônio, este lhe entregou as chaves da senzala e lhe ordenou que fechasse os escravos que não tinham fugido. Ele foi acompanhado de certo José Francisco de Paulo, a quem o administrador entregou duas pistolas carregadas. Apenas no dia seguinte viu o cadáver do ferreiro Manoel.

Os réus presentes nada contestaram.

A próxima testemunha informante foi Moisés Moçambique, de 45 anos, trabalhador de machado e enxada. Estava na fazenda desde que esta havia sido comprada. Pelos autos do processo, não é possível saber o ano. Mas havia três ele já tinha fugido de João Antônio e servia o comendador na cidade. Voltou à fazenda, como sabemos, por ordem de Boaventura, para encontrar e fazer voltar os parceiros fugidos. Era a pessoa certa e não por haver sido batizado com o nome bíblico de Moisés - "era bem prático dos matos da fazenda”. Mas João Antônio não permitiu. Disse que eles não estavam mais no mato, mas na cidade, com o comendador. E prometeu-lhe uma "boa molhadura", caso acreditasse. Como Moisés se conservasse cético, o administrador o entreteve em recados para os vizinhos, acerca dos parceiros fugidos.

Sobre a noite da ronda, acrescentou ao já sabido que João Antônio dera ordens para desferir foiçadas em qualquer um que não se identificasse e contou que reconhecera a voz de Antônio Pernambuco, que gritava " $m a t a, m a-$ $t a$ ", e a do réu também presente Silvestre, que gritava "não mata, ensina sô". Acabou a noite dormindo fechado no paiol, junto com outros escravos.

- Mata! Mata!

- Mata não, ensina só!

Era a pedagogia da escravidão.

Na acareação, Antônio Pernambuco negou que fosse o único a gritar "mata, mata", mesmo que fosse ele o primeiro a investir contra o ferreiro, e acrescentou que "não havia razão em só quererem imputar a ele o fato", exceto se fosse "por raiva que lhe tinham em razão de ele ser pardo". E confirmou que o compadre Silvestre advertira "mata não, ensina sô". E mais não disse.

Ser pardo era motivo de ódio, ser liberto também, tudo se prestava a maus sentimentos, naquele tempo e naquela fazenda.

A terceira testemunha informante foi o escravo Narciso. Dessa vez, o auto traz a sua idade: 28 anos. Disse que se não estivesse doente também 
teria fugido com os demais. Detalhou mais uma vez o papel truculento de João Antônio nos assassinatos de Basílio e Inês, acrescentando detalhes. A morte de Inês estava ligada à sorte de um outro Basílio, também escravo da fazenda, com quem mantinha "relaçôes ilícitas" (talvez outro casamento não sancionado pela Igreja Católica). Segundo a versão de Narciso, ela e o marido foram acusados de haver furtado um dinheiro da casa. Assustada, Inês fugiu (não era a primeira vez que fugia; da outra vez, voltara apadrinhada). Recapturada por um capitão-do-mato, João Antônio a surrou, deulhe cutiladas na cabeça e até de uma pedra se serviu para ferir suas costelas. Dois dias depois, ela faleceu. Narciso disse que viu tudo isso acontecer.

A quarta foi o liberto Luís. Voltou a dizer que ignorava o motivo pelo qual os escravos fugiram e adicionou alguns detalhes ao que já havia contado. Sobre o encontro fortuito com o escravo fugido Manoel Cabungu, na tarde do dia 13 de fevereiro, que ensejou a ronda de noite, acrescentou que vira "sair de dentro do galinheiro do réu presente, Silvestre, o preto fugido Manoel Cabungü". Silvestre tinha um galinheiro, como se vê. Trata-se de um exemplo do que os livros de história chamam de economia própria dos escravos. Um galinheiro aqui, um chiqueiro ali, umas roças acolá: de variadas maneiras os cativos davam um jeito, com a anuência do senhor (imprescindível), de instituir zonas de relativa autonomia na rede da escravidão. Mesmo na Ponte de Tábuas, uma fazenda desgovernada. ${ }^{18}$

Acrescentou detalhes também sobre como os escravos tentaram matá-lo. Disse que Dionísio tinha uma faca e Antônio repolho uma foice. Quando com eles lutavam, chegou Antônio Pernambuco, que gritava "mata esse diabo?" Conseguiu se desvencilhar do grupo e atirar-se no rio, com Pernambuco em seu encalço. Acareado com os réus, falou primeiro Antônio Pernambuco, dizendo que Dionísio e Antônio repolho não andavam armados e, naquela noite, só traziam uns pequenos paus. Silvestre e Valentim confirmaram. Luís sustentou o que dissera e acrescentou que Valentim, na ocasião, também gritava ("para o lado que estava ele respondente"): "Atirem! Olhe lá não molhem a espoleta!". Valentim negou.

Luís voltou a dizer também que Narciso integrava a ronda do ferreiro.

O próximo a ser ouvido foi o sobrinho de João Antônio, o feitor Francisco. Ele nem conhecia os escravos fugidos, pois chegara na fazenda no dia 7 de janeiro, uma semana após a fuga. Vinha de São Gonçalo, que fi- 
ca entre Praia Grande e Maricá. Disse que não sabia dos motivos dos escravos para fugir, mas que ouvira dizer que fora "sem causa". Mas até ele achou que era o tio que amarrava algum escravo, ao ouvir os gritos de "mata e atira". Tudo indica que sobreviveu apenas graças à intervenção do réu Silvestre. Segundo contou, ao se dirigir para o local de onde vinham os gritos, topou com um vulto que lhe deu uma "bordoada". Voltando-se para lutar, caiu-lhe em cima "uma turma grande de pretos que o atacaram, dando-lhes pancadas, uns com paus, outros com foices". Caído no chão, escutou alguém gritar: "Não mata esse não, que não tem culpa?". Francisco aproveitou a ocasião para fugir, mas antes que chegasse à casa, ainda no terreiro, alguém ainda lhe deu outra bordoada. Francisco não pôde reconhecer os réus presentes, "por estar a noite bastante escura". Chovera muito naqueles dias, o tempo devia estar nublado. E era dia sem lua. ${ }^{19}$

A seguir foram ouvidos quatro moradores das redondezas, todos lavradores entre 40 e 60 anos, dois casados e dois solteiros, três brancos e um pardo. Três deles, incluindo o pardo, só souberam do crime por ouvir dizer e não sabiam que escravos haviam assassinado o ferreiro. $\mathrm{O}$ outro esteve na fazenda no dia seguinte ao do assassinato. Soube do acontecido pelo liberto Luís e o viu, e mais o feitor Francisco, muito feridos. Contou também que ouviu na fazenda "que quando os mesmos pretos cometeram o assassinio diziam formais palavras 'mata o senhor João Antônio". Os réus presentes negaram.

Finalmente foi a vez de João Antônio da Silva Ferreira ser ouvido. Era a primeira e seria a última vez a ser importunado com perguntas. Era administrador da fazenda desde junho de 1844. Não completou os 6 anos, pois foi demitido em março de 1850.

A primeira pergunta que lhe fizeram dizia respeito à sua capacidade de fazer os escravos se comportarem bem e lhe obedecerem. A pergunta foi "se os réus presentes e todos mais escravos da fazenda da Ponte de Tábuas, durante o tempo da sua administração, sempre se portaram bem e com obediência?" Ele respondeu que "sempre se portaram bem e com obediência... e que só nos últimos tempos... é que foi conhecendo nos mesmos pretos pouca vontade de o servir". Mentira. Inês morrera já fazia dois anos. Foi perguntado a seguir se sabia a razão da fuga. Respondeu que não, que sempre tratara bem os escravos, "não julgando que era tratar mal o castigar os pretos quan- 
do mereciam e fazê-los trabalhar quando deviam". De fato, a administração da fazenda não precisava de nada além. O problema era que João Antônio, ao que parece, não sabia fazer o seu trabalho direito - deixava-se inflamar pelo ódio, dava cutiladas com facão, batia com pedra. $\mathrm{O}$ ter nascido em Portugal, numa época em que a escravidão já era uma lembrança longínqua de quase 100 anos, pode ajudar a compreender o modo como conduzia as coisas na Ponte de Tábuas. ${ }^{20}$ Mas não era por falta de escola que ele agia como agia, eu acho. Era a escolha que ele fazia, no calor da hora, se é que se pode falar de um calor da hora que dure anos. Acho que ele era um indivíduo muito pouco arteiro.

Afirmou que era mentira que os escravos fugidos nunca mais tiveram contato com os de casa, como disseram todos os depoentes que o antecederam. Disse que "de casa é que se forneciam os mantimentos que eles no mato necessitavam", e acrescentou que "até algumas vezes dormiram nas senzalas". Se era verdade, melhor para os escravos. E mais provada ficava a dificuldade que tinha de impor a sua autoridade naquela casa. Como o sobrinho, disse que ouvira os escravos gritarem "mata esse João Antônio", enquanto matavam o ferreiro. Contou que naquele dia fora informado pelo sobrinho sobre o encontro com um dos escravos fugidos e ordenara a ronda, sem dar detalhes sobre quem mandara à caça aos fugitivos. E repetiu a história contada por Maria do Rosário, acerca da criança adoecida que o impedira de sair com os demais. Quando enfim pôde sair, já entrava pela porta da cozinha o seu sobrinho, coberto de sangue, "de sorte que ele respondente ficou fixado na sala com os feridos, onde passou toda a noite". João Antônio passou a noite fixado na sala, e os escravos passaram quase três meses fixados nas matas da fazenda.

O problema da obediência dos escravos voltou à baila. Perguntaram por que os escravos pretendiam matá-lo, se lhe obedeciam, como afirmara. Ele respondeu que julgava que por haver Pernambuco os aliciado, após ser castigado porque "andava aprendendo feitiço com o negro do brigadeiro Sampaio". Sobre Pernambuco, disse mais: que o nomeara feitor, posto no qual permaneceu por dois anos, mas o demitiu "não só pelas ditas feitiçarias em que andava metido com os negros do brigadeiro Sampaio, como porque era ladrão".

Sobre Inês, disse que morreu de amigdalite, muito tempo depois de ser castigada "por fujona”. Sobre Basílio deu a mesma versão que Maria do 
Rosário parece ter dado: que após ser castigado por roubar feijão, metido no tronco, recusou-se a comer e, após 12 dias, faleceu.

Os réus presentes o contestaram. $\mathrm{O}$ escrivão não anotou quem disse o quê, mas negaram que tivessem gritado "mata João Antônio". Disseram que fugiram por causa dos maus-tratos e que ele "os tratava cruelmente, que lhes dava pancadas sem razão e que até tirando da fazenda bois e carneiros para vender, tudo isso atribuia aos escravos da fazenda e os castigava". Que ele mentia sobre Inês e Basílio. Este morrera dois dias depois da surra e não 12. Sobre Inês, contaram que a morte dela estava ligada ao dinheiro que havia sumido na casa, que João Antônio suspeitava ter sido roubado por Basílio Angola, parceiro de Inês. E deram mais detalhes sobre a surra. João Antônio a surrou, depois deu-lhe com palmatória nas solas dos pés, bateu com uma pedra sobre as suas costelas e enfim a meteu em ferros, "não tendo cuidado de a tratar, e que desses ferimentos foi que a preta morreu".

$\mathrm{O}$ último a falar foi Antônio Pernambuco, que negou a acusação de feitiçarias, explicando que quando "o negro do brigadeiro Sampaio" ia à fazenda, não tratavam de furtos nem feitiçarias, que ele ia "para dar-lhe alguns remédios para uma doença que lhe costumava dar", sobre a qual ele já tinha se queixado ao administrador, que nunca tomara providência. Concluindo, disse que jamais furtara nada da fazenda e desafiou: "Pois que nesta Vila não havia ninguém que fosse capaz de dizer que o viu vender alguma coisa da fazenda, salvo esteiras."

Silvestre tinha um galinheiro, Pernambuco fazia esteiras nos seus dias de folga e as vendia na vila... a vida não precisava ser aquele inferno. Mas naquela fazenda era. A crer no que disseram os escravos, João Antônio não tinha mesmo limites. Roubava os bois e carneiros do comendador, para revendê-los e jogava a culpa nos escravos. E para conferir credibilidade à farsa, batia, batia e batia.

Antônio Pernambuco bem podia estar aprendendo "feitiços" com o "negro do brigadeiro Sampaio", pois ambos deviam compartilhar uma cultura ainda fortemente africana, cujas manifestações João Antônio nomeava feitiçarias. Afinal, o tráfico transatlântico revigorou a África no Brasil incessantemente, até 1850 . Isso não quer dizer que a Igreja Católica falhava em seu propósito de converter os escravos. Esse esforço havia. Em 1816, no início da viagem que fez a Minas Gerais, o botânico Saint- 
Hilaire pôde testemunhá-lo. E descreveu a cena tão bem, que vale a pena contar aqui. No terceiro dia de viagem, dormiu num rancho de beira de estrada. Adormeceu ao som de uma ladainha entoada por um grupo de "negros novos", que, acocorados em torno de uma fogueira, se esforçavam por repetir o catecismo recitado por um escravo ladino. Ele acrescentou que a noite era fria, morcegos voavam errantes e porcos aplacavam a fome, atraídos pelos restos de comida das caravanas. Foi assim que ele adormeceu, entre bichos, homens e Jesus. ${ }^{21}$

Uma apreciação ligeira do papel da Igreja Católica e do Cristianismo no nosso passado escravocrata se contenta em acusar ambos de conivência com a escravidão. Isso não deixa de ser verdade. Clérigos compravam e se serviam de escravos e ordens importantes e ricas possuíam propriedades tocadas por escravos, como jesuítas, beneditinos e outras. No entanto, os cristãos, desde o apóstolo Paulo, estão proibidos de duvidar da natureza humana - portanto, divina - de qualquer pessoa, seja senhor ou escravo. Aliás, ao contrário do que juram os nossos alunos de graduação (foram ensinados que os padres duvidavam se os escravos tinham alma), a Igreja Católica condenou a escravidão dos "Indios, \& todas as mais gentes" já em 1537, em bula do papa Paulo III. ${ }^{22}$ De toda forma, talvez fosse melhor ser escravo numa sociedade cristã, uma vez que a convicção de compartilhar uma única humanidade deve ter tido algum efeito no dia a dia. O padre Antônio Vieira, falando aos desvalidos de um engenho da Bahia do século XVII, exaltou os escravos e teve pena dos senhores - e não estava fingindo.

Voltando a Pernambuco, também pode ser que ele falasse a verdade e tivesse "uma doença que lhe costumava dar". Inventários post-mortem de fazendeiros do Rio de Janeiro, abertos na década de 1820 , revelam que entre $1 / 5$ e $1 / 4$ da população escrava apresentava algum tipo de enfermidade. A mais comum era a que chamavam "rendido da virilha", que parece indicar hérnia, que remete à idéia do esforço físico exigido dos escravos. Também freqüentes eram os cegos, com doença do peito, além da descrição genérica "feridas". ${ }^{23}$ Vai ver que Pernambuco tinha alguma doença do peito. Pode ser. Andava chegando muito estrangeiro da África, naqueles anos, e maiores intercessões de distintas esferas microbianas provocavam mais doenças. De qualquer forma, João Antônio não estava nem aí. 
De quatro a oito de maio foram ouvidos mais dois lavradores e, novamente, os réus. Os primeiros, como quase todos os lavradores das redondezas, sabiam do caso apenas por ouvir falar.

Perguntado a Antônio Pernambuco se ele tinha fatos a alegar em sua defesa, ele disse que sim: o mau tratamento dado aos escravos por João Antônio. E acrescentou o óbvio: "O qual foi a causa deles todos fugirem de casa e das desordens que tem aparecido na fazenda." Admitiu que fora o primeiro a dar uma foiçada no ferreiro, mas acrescentou que em seguida, a vítima ainda de pé, arremessaram sobre ela, armados de foices, Silvestre, Valentim, Constantino, Joaquim, Dionísio e Tomás. Esses dois, Joaquim e Tomás, foram citados pela primeira vez nessa ocasião. Não voltaram a aparecer no processo. Certamente a idéia não era estabelecer culpas e determinar punições individuais, mas castigar exemplarmente. Era conforme o espírito da época. Pernambuco disse também que após o assassinato do ferreiro topou com um vulto, no qual deu com a foice, que depois soube ser Luís, o liberto. Mas negou que tivesse atentado contra a vida do feitor Francisco.

Valentim também alegou em sua defesa os maus tratamentos de João Antônio e acusou-o de roubar a ele, Valentim: "Algumas vezes chegou a tomar-lhe suas roças de milho." Valentim tinha seus roçados de milho, como se vê. Sobre a morte do ferreiro, confessou que dela participara, armado de uma foice, e citou também os escravos João Moleque, Constantino, Joaquim e Dionísio como cúmplices do assassinato.

Silvestre não acrescentou nada ao que já contara, exceto que Dionísio e Constantino também participaram da morte do ferreiro.

Dionísio e Constantino já estavam presos e foram interrogados no dia 14 de maio.

Dionísio era um africano de 32 anos presumidos, solteiro, pedreiro e estava havia seis anos na fazenda (nenhum escravo que informou o tempo na fazenda estava lá havia mais tempo do que isso). O depoimento dele lançou novas luzes sobre os assassinatos de Basílio e Inês, sobre a intrincada e conflituosa teia de relações entre os moradores daquela fazenda e comprometeu mais ainda o "pardo" Antônio Pernambuco.

Na primeira resposta de Dionísio já há uma pérola. Perguntado por que fugiu, respondeu que "conquanto não fosse ele preto costumado a fugir, todavia nessa ocasiāo não pôde deixar de fugir, por não poder suportar o 
tratamento bárbaro" dispensado a ele a aos demais por João Antônio. Ele podia estar mentindo (embora fosse fácil desmenti-lo, se estivesse), mas contava com que todos soubessem que no mundo havia os "costumados a fugir" e os outros, mais pacientes. Ele queria que acreditassem que pertencia ao segundo tipo, que não era o de Inês, por certo, pois ao menos duas fugas dela são referidas no processo. A alegação de Dionísio lembra a observação de Antonil, elaborada cerca de 150 anos antes daqueles dias, a propósito dos escravos que conhecera. Dizia o jesuíta: "Uns chegam ao Brasil muito rudes e muito fechados e assim continuam por toda a vida. Outros, em poucos anos saem ladinos e espertos, assim para aprenderem a doutrina cristā, como para buscarem modos de passar a vida." ${ }^{24}$ Entre o rude e fechado, por uma lado, e o ladino e esperto, por outro, situavam-se os escravos, cada um do seu jeito. Havia tantas possibilidades de ser escravo que fica difícil dizer como era exatamente Ser Escravo no Brasil. Faço um trocadilho com o livro de Kátia Mattoso, ${ }^{25}$ mas o que quero é chamar a atenção para o fato de que as categorias e conceitos que os historiadores inventam, ou de que se apropriam, para descrever a sociedade escravocrata são tentativas (bem intencionadas, úteis e até indispensáveis) de dar conta de uma multidão de destinos que, como sempre, dependeu muito de escolhas individuais. Por outras palavras, era-se o escravo que cada um se dispunha a sê-lo, do jeito que mais convinha à razão e ao estômago de cada um. Ou não se era, no caso de alguns.

Dionísio também acusou João Antônio de furtar bens da fazenda, vendê-los e culpar os escravos pelo roubo. $\mathrm{O}$ depoimento dele sobre a morte de Basílio e Inês ajuda a montar o quebra-cabeça que até aqui vimos construindo. Havia mais de um Basílio na fazenda: um era marido de Inês, africano de Angola, e o outro, crioulo, mantinha "relaçôes ilícitas e amorosas" com a escrava Maria do Rosário, o que acendeu a ira de João Antônio. Miguel Congo já aludira ao ciúme dele por Maria do Rosário como a causa do assassinato do escravo crioulo. Dionísio confirmou e acrescentou detalhes. Disse que ao saber do caso João Antônio "logo procurou um pretexto para castigar ao dito preto" e, numa noite, quando estavam todos reunidos no paiol, o administrador anunciou que faltava um saco de feijão e acusou Basílio crioulo de tê-lo roubado e vendido na vila. Mandou amarrá-lo num esteio e o surrou, com direito a estocadas com facão sobre as costelas 
e algumas cutiladas na cabeça. No dia seguinte (ou dois dias depois, segundo outras versões) Basílio estava morto. Quanto à morte de Inês, também nela a escrava Maria do Rosário esteve envolvida, segundo Dionísio. Ele contou que ela teria dado um dinheiro (roubado da casa) a Basílio Angola "para comprar alguma coisa que a fizesse ficar forra". Quando João Antônio deu por falta dele, Maria do Rosário teria culpado o casal pelo furto. Aterrorizados, os dois fugiram, mas logo foram capturados e trazidos de volta à fazenda, onde João Antônio fez o de sempre, com os requintes de crueldade costumeiros. Após espancá-los, mandou-os trabalhar, mas Inês não podia, alquebrada pelas pancadas. Teria sido nessa ocasião que o administrador se valera de uma pedra, atingindo-a na cabeça e no pescoço. $\mathrm{O}$ escrivão anotou assim o que se seguiu: "De sorte que a negra não pôde resistir ao serviço e por fim foi obrigada a deitar-se." João Antônio então mandou metê-la no tronco, do qual ela só sairia no dia seguinte, já morta. Na verdade, como veremos a seguir, a saga da preta Inês pode ter sido um pouco diferente, mas nada que altere muito essa história macabra.

A única coisa que Maria do Rosário podia comprar para ficar forra era uma carta de alforria - ao seu senhor, o comendador Boaventura Ferreira Maciel. A declaração do escravo, assim um tanto truncada, chama a atenção. Vivendo perto do liberto Luís (e certamente de muitos outros forros que não aparecem no processo), havia de saber "a coisa" que poderia fazêla forra. Além disso, Basílio não poderia comprar a carta, escravo que era. Apenas ela, ou um protetor, podiam tentar adquirir a liberdade - e Boaventura venderia se quisesse. ${ }^{26} \mathrm{~A}$ fala do escravo pode estar encobrindo acertos que muito raramente aparecem nas cartas de alforria pagas - entre os escravos e entre os escravos e pessoas livres. A ser verdade essa versão, Basílio podia, por exemplo, estar guardando o dinheiro que Maria do Rosário dava um jeito de obter. Ou podia ser um elo entre ela e uma pessoa livre de confiança presumida - que talvez fosse uma daquelas que, mesmo não sendo advogados, se especializavam em escrever petiçóes à justiça (algumas haviam de ser simpáticas à causa dos escravos). Mas é impossível saber.

Sobre a noite do crime, Dionísio disse que chovia tanto naqueles dias que eles resolveram tomar padrinho e voltar para a fazenda. Estavam abrigados na casa do anil quando apareceu alguém e, supondo eles que estavam cercados, fugiram imediatamente. Depois Antônio Pernambuco 
apareceu, disse que tinham morto um homem e que "eles eram maus companheiros por que fugiram".

Constantino não sabia o nome dos pais, tinha 24 anos e estava na fazenda havia seis. Possivelmente, era um africano no Brasil desde garoto. A história do assassinato de Inês adquire seu contorno final nesse depoimento. Contou do dinheiro que Maria do Rosário dera a Basílio Angola (ignorava para que fim) e disse que tendo o administrador "dado por falta do dinheiro, agarrou o dito preto e o surrou e ao depois o meteu no tronco". De noite, a mulher dele, Inês, foi soltá-lo às escondidas. Fugiram. Foram apanhados na fazenda de uma tal Dona Maria Tereza, que não devia ficar longe e onde todo mundo devia estar sabendo o que se passava na Ponte de Tábuas. Na volta, João Antônio fez o que fez, "de sorte que a preta morreu", como escreveu o escrivão.

Sobre a noite de 13 de fevereiro, disse que quando perceberam que alguém chegava à casa do anil, fugiram ele, Dionísio, Ambrósio, Joaquim, Manoel, Manoel Cabangu e Tomás. E que depois veio Antônio Pernambuco e "disse que eles não eram homens porque tinham fugido, mas que ele tinha morto a João Antônio".

Ambos foram acareados com os Antônio Pernambuco, Valentim e Silvestre. Os dois últimos disseram que Dionísio e Constantino mentiam, que também eles mataram o ferreiro. Antônio Pernambuco acrescentou que Constantino "foi o segundo que o ajudou a dar pancadas no dito ferreiro". Eles negaram.

Quatro dias depois, no dia 18 de maio, o Juiz Municipal interino Joaquim Lopes da Silva Vianna Couto mandou soltar Dionísio e lançar o nome de Constantino no rol dos culpados. Apesar de Valentim e Silvestre haverem dito que julgavam que ambos tinham participado da morte do ferreiro, ficava estabelecido que como eles não podiam "afiançar" que os dois haviam participado diretamente do assassinato, nenhum indício sólido havia para acusar Dionísio. Já Constantino era um caso diferente, pois Antônio Pernambuco declarara que este fora o segundo a se precipitar sobre o finado e disso "ele réu estava lembrado".

$\mathrm{O}$ auto seguinte contém o libelo acusatório, apresentado pelo promotor público Dídimo Agapito da Veiga, no dia 24 de maio. Ele acusou Antônio Pernambuco, Silvestre, Valentim e Constantino de terem matado o ferreiro e ferido Luís e Francisco, com a agravante de tê-lo feito à noi- 
te, "com superioridade em forças e armas" (de modo que "os ofendidos não podiam defender-se"), e com premeditação e "ajuste" para praticar tais crimes. Concluiu que os réus estavam incursos na disposição dos artigos 192 e 205 do Código Criminal e pediu a pena de galés perpétuas.

No dia 27 de maio, o juiz mandou que o administrador da Ponte de Tábuas (àquela altura João Antônio já estava demitido) fosse citado para apresentar na sessão do júri, a ser realizada no dia seguinte, os escravos Pedro Cabinda, Moisés Moçambique e Narciso Moçambique. Os autos do processo, no entanto, não registraram a presença deles no tribunal.

A sessão foi presidida por João Lins Vieira Cansanção de Sinimbu, uma pessoa muito importante no Brasil do século XIX. Além de juiz de direito em Cantagalo e Nova Friburgo, na década de 1850, foi presidente das províncias de Alagoas (1840), Sergipe (1841), Bahia (1856) e Rio Grande do Sul (1855). Foi também deputado-geral nas legislaturas de 1842 a 1844 e de 1853 a 1856. Presidiu o Senado entre 1887 e 1888. Foi ministro dos Negócios Estrangeiros em 1859, da Agricultura e interino da Justiça em 1862, e organizou o $27^{\circ}$ Gabinete de 1878, ficando com a pasta da Agricultura e interinamente na da Guerra, Fazenda e Estrangeiros. Foi Conselheiro de Estado, nomeado em 1882, do Conselho de Sua Majestade, era Grande do Império, Comendador da Imperial Ordem de Cristo e da Rosa, Grã-Cruz da Legião de Honra, da França, da Coroa de Ferro d'Áustria, e dos Guelfos, de Hannover, além de sócio do IHGB, desde $1840 .{ }^{27} \mathrm{O}$ que fazia ele entre os miseráveis escravos da Ponte de Tábuas? Gilberto Freyre, formado numa época em que a escravidão era ainda uma lembrança quase palpável, escreveu sobre aspectos dessa proximidade entre superiores e inferiores no Brasil daquela época. Fato é que Sinimbu e Antônio Pernambuco se conheceram.

A sessão do júri começou às dez da manhã do dia 28 de maio, na Câmara Municipal, quando Sinimbu fez tocar a campainha declarando aberto o julgamento. Presentes estavam, registrados nos autos, além do juiz, o promotor público da comarca, Dídimo Agapito da Veiga, o curador dos escravos, Luís Francisco Torres, o escrivão, uma meia dúzia de policiais e oficiais de justiça e mais 12 jurados. Os escravos se conservavam em sala anexa, exceto quando foram interrogados ou trazidos para acareação.

O escrivão, que não era o mesmo José Rodrigues da Costa Bravo dos demais autos, mas o interino do júri, José de Souza Maia, dá a impres- 
são de ter se empenhado em redigir a ata do julgamento, no qual falaram o promotor, o curador e os quatro escravos réus. Mas falhou em registrar muito do que foi dito, conforme se pode ler no auto intitulado Ata da Sessão do Júri. A certa altura ele escreveu: "Resumo logo com a maior clareza possivel toda a matéria de acusação e defesa e as razões expendidas, pró e contra." Resumiu assim e mais não disse. De toda forma, sabemos que o promotor abriu o Código Criminal e mostrou os artigos e parágrafos nos quais os réus estavam incursos e leu o libelo acusatório já conhecido. Em seguida, a palavra foi dada ao curador, que fez o que estava obrigado a fazer e defendeu os réus. Não sabemos o que ele disse e alegou. João Antônio deve ter sido citado, por certo. A palavra retornou ao promotor, que respondeu ao curador, que tornou a fazer a defesa dos réus.

Em certa ocasião (não fica claro em que altura do julgamento), os réus foram chamados a responder a perguntas do juiz da sessão, Sinimbu. $\mathrm{O}$ primeiro foi Antônio Pernambuco. Disse que só soube do que era acusado após ser preso e ignorava quem matara o ferreiro, o qual, aliás, não conhecia. Manoel era novo na Fazenda Ponte de Tábuas, quando chegou à propriedade os escravos já estavam fugidos (ou estavam prestes a fugir, como sugere o depoimento a seguir). Foi lá para morrer. A presteza demonstrada pelo ferreiro (segundo Maria do Rosário, ele convocou João Antônio a começar a ronda, dizendo que "eram horas") seria para impressionar o chefe? Pode ser, mas diz algo sobre o papel da população livre no controle sobre os escravos.

Os escravos podiam ser a maior parte da população em certas regiôes do Brasil, de maior dinamismo econômico, mas, no geral, a presença da população livre era expressiva (ao contrário do que acontecia em algumas ilhas do Caribe). Joaquim Nabuco dizia que não escrevia para os escravos, mas para os livres, depositários da responsabilidade de fazer a abolição. Ele sabia que se os escravos "acordassem", deles daria cabo a "lei de Lynch". ${ }^{28}$ Hoje diríamos: linchamento. Ele escreveu que os escravos eram "homens sem defesa" ${ }^{29}$ Manoel Custódio de Carvalho, que Deus o tenha, pode ter sido vítima da impaciência das pessoas livres, fossem ricas ou remediadas, ante a impaciência dos escravos. Nem mesmo os libertos, a ser exemplar o comportamento de Luís, tinham paciência com os escravos. Bem, ao menos na Ponte de Tábuas era assim. 
Antônio Pernambuco contou que na noite chuvosa do dia 13, quando estavam abrigados sob um telheiro, surgira um vulto e eles logo se puseram a surrá-lo com foices e cacetes. Na fuga de volta para o mato, que sucedeu ao crime, encontraram com mais duas pessoas, numa das quais ele deu uma pancada. Mas não sabia quem era "pela escuridão da noite".

A seguir foi a vez de do crioulo Silvestre. Disse também não saber o autor da morte de Manoel. Acrescentou que ele e os demais escravos fugidos sumiram no mato por temor dos castigos de João Antônio e deu como exemplo o assassinato de Basílio. Contou que na noite do crime ele e demais parceiros " não podendo mais suportar as chuvas e o mau tempo que fazia" voltaram à sede da fazenda, de modo a se abrigarem num telheiro. Quando perceberam que deles se aproximava um vulto, procuraram fugir, Antônio Pernambuco à frente. Disse que após este dar uma foiçada, ele e outros deram pancadas também. Sobre Luís e Francisco, afirmou que não dava para reconhecer ninguém devido à escuridão e só soubera que eles foram feridos após ser preso. Sustentou que apenas depois de preso soube que um deles era "o preto Luis" e que Antônio Pernambuco havia dado uma pancada nele. Confessou que estava armado com uma "foicinha velha" e com o cabo ferira o vulto. Perguntado por que matara o homem, respondeu que porque assim vira Antônio Pernambuco fazer. Não conhecia Francisco. $\mathrm{O}$ ferreiro, apenas de vista, pois ele chegara à fazenda poucos dias antes da fuga. Luís era conhecido seu, por ser morador na Ponte de Tábuas.

Valentim também disse não saber quem matara Manoel, mas foi mais incisivo sobre a crueldade de João Antônio: mostrou ao júri as cicatrizes num corpo, por certo, já velho (nesse auto a idade anotada é 48 anos). Contou que naquela noite, exaustos, abatidos pelo frio e pela fome, resolveram voltar a casa, de modo a "pedirem proteção do administrador".

De uma lado a fome e o frio, do outro, o administrador: é triste constatar mas, para aqueles escravos, não havia mais nenhum sertão por onde se embrenhar e se perder. Não havia mais um sertão físico, na forma de uma extensão de terra que pudessem cruzar incógnitos de forma a distanciar-se daquela fazenda. Inês foi logo recapturada na fazenda de uma tal Dona Maria Tereza. Vai ver em torno da Ponte de Tábuas só existiam outras fazendas igualmente tocadas por escravos. E também não havia mais sertão na forma de alguma proteção possível de alguém que valesse mais 
que João Antônio. Exceto para o escavo Moisés, claro, que fugiu e foi servir a Boaventura, na vila de Nova Friburgo. E os escravos ficaram fixados nas matas, assim como João Antônio ficou fixado na sala, durante toda a noite do dia 13 de fevereiro.

Sobre o crime, disse que Antônio Pernambuco foi o primeiro a avançar sobre o ferreiro e que quando ele deu pancadas no vulto, este já se encontrava morto. Acrescentou que ao fugir do lugar viu Antônio Pernambuco lutando com outros vultos.

Constantino Moçambique foi o último a ser interrogado perante o júri. Não sabia por que estava preso nem quem matara o ferreiro. Não estava mais no local do crime na hora da morte, feita, soube depois, por Antônio Pernambuco e outros. Concluiu dizendo que nem arma tinha, que apenas carregava um cobertor.

Antônio Pernambuco e Silvestre foram então trazidos de volta à sala e afirmaram que ele trazia, sim, uma foice. Pernambuco acrescentou que ele também dera foiçadas no ferreiro. Constantino negou.

Após interrogatório e acareação dos réus, e pronunciamentos da acusação e da defesa, "achando-se a causa em estado de ser decidida", como anotou o escrivão, Sinimbu instruiu os jurados nas 18 perguntas para as quais deviam encontrar respostas, de modo a fazer justiça. Recolhidos a uma sala "a portas fechadas", os 12 jurados deveriam responder se os réus mataram o ferreiro e feriram Luís e Francisco, se o fizeram em circunstâncias que agravavam o crime, e se havia atenuantes. Tais circunstâncias estavam estipuladas nos parágrafos $1^{\circ}, 6^{\circ}, 8^{\circ}$ e $17^{\circ}$ do Artigo 16, do capítulo III do Código Criminal do Império do Brasil. São elas, respectivamente: ter cometido o crime a noite ou em local ermo; haver no delinqüente superioridade em sexo, forças ou armas, de maneira que o ofendido não pudesse se defender; ter havido premeditação; e, finalmente, ter precedido ajuste entre dois ou mais indivíduos com o propósito de cometer-se o crime.

A conclusão do júri está sintetizada no quadro a seguir. Constantino está ausente, pois foi absolvido da acusação de haver matado o ferreiro, única coisa a que os jurados foram instruídos a se pronunciarem. 


\begin{tabular}{|c|c|c|c|c|c|c|}
\hline & \multicolumn{2}{|c|}{$\begin{array}{c}\text { Antônio } \\
\text { Pernambuco }\end{array}$} & \multicolumn{2}{|c|}{ Valentim } & \multicolumn{2}{|c|}{ Silvestre } \\
\hline & sim/não & votos & sim/não & votos & sim/não & votos \\
\hline Matou o ferreiro? & $S$ & 12 & $S$ & 12 & $S$ & 12 \\
\hline Art. $16 \$ 1^{\circ}$ ? & $S$ & 11 & $S$ & 11 & $S$ & 11 \\
\hline Art. $16 \$ 6^{\circ}$ ? & $S$ & 10 & $S$ & 9 & $S$ & 11 \\
\hline Art. $16 \$ 8^{\circ}$ ? & $S$ & 7 & $S$ & 10 & $S$ & 7 \\
\hline Art. $16 \$ 17^{\circ}$ ? & $\mathrm{N}$ & 7 & $\mathrm{~N}$ & 7 & $\mathrm{~N}$ & 10 \\
\hline Atenuantes? & $\mathrm{N}$ & 11 & $\mathrm{~N}$ & 8 & $\mathrm{~N}$ & 10 \\
\hline Feriu Luís? & $S$ & 9 & $\mathrm{~N}$ & 7 & $\mathrm{~N}$ & 12 \\
\hline Art. $16 \$ 1^{\circ}$ ? & $S$ & 11 & - & - & - & - \\
\hline Art. $16 \$ 6^{\circ}$ ? & $S$ & 7 & - & - & - & - \\
\hline Art. $16 \$ 8^{\circ}$ ? & $S$ & 11 & - & - & - & - \\
\hline Art. $16 \$ 17^{\circ}$ ? & $\mathrm{N}$ & $\mathrm{U}$ & - & - & - & - \\
\hline Atenuantes? & $\mathrm{N}$ & 10 & - & - & - & - \\
\hline Feriu Francisco? & $\mathrm{N}$ & 9 & $\mathrm{~N}$ & 12 & $\mathrm{~N}$ & 11 \\
\hline Art. $16 \$ 1^{\circ}$ ? & - & - & - & - & - & - \\
\hline Art. $16 \$ 6^{\circ}$ ? & - & - & - & - & - & - \\
\hline Art. $16 \$ 8^{\circ}$ ? & - & - & - & - & - & - \\
\hline Art. $16 \$ 17^{\circ}$ ? & - & - & - & - & - & - \\
\hline Atenuantes? & - & - & - & - & - & - \\
\hline
\end{tabular}

Os três foram condenados, por unanimidade, pela morte do ferreiro, sem atenuantes e incursos em todas as circunstâncias agravantes, exceto a contida no parágrafo $17^{\circ}$ - o que significa que o júri entendeu que os escravos não haviam combinado matar o ferreiro. $\mathrm{O}$ exame da distribuição de votos é curioso. Antônio Pernambuco e Silvestre quase escaparam de serem enquadrados no parágrafo $8^{\circ}$, que versava sobre a premeditação do crime. Não encontro, nos autos, motivo pelo qual os jurados estavam convencidos, em maior número, da culpa de Valentim quanto a isso. $\mathrm{O}$ escrivão pode ter se enganado. Até porque Valentim foi o que mais se aproximou de ter reconhecidas circunstâncias atenuantes na morte do ferreiro: quatro jurados votaram a seu favor, contra dois no caso de Silvestre e apenas um quan- 
to a Antônio Pernambuco. É possível que o gesto de exibir ao júri as cicatrizes das surras que levara de João Antônio tenha surtido algum efeito. De qualquer maneira, apenas um jurado achava que o inferno na Ponte de Tábuas era condição atenuante até mesmo para Antônio Pernambuco. Apenas para um jurado, em 12, era inaceitável o que acontecia na fazenda.

Outra coisa chama a atenção na decisão dos jurados. Ninguém foi responsabilizado pelos ferimentos no feitor Francisco, e Antônio Pernambuco foi responsabilizado sozinho pelos ferimentos feitos no liberto Luís. $\mathrm{O}$ próprio liberto, no interrogatório que respondeu no dia 21 de fevereiro, afirmou que primeiro o ferira Dionísio, depois Antônio "repolho" e só então o escravo Pernambuco. Mas os dois primeiros foram dispensados no meio do caminho, por assim dizer, sendo que o segundo sequer chegou a ser ouvido. Já fiz referência, mais acima, ao desinteresse da justiça em investigar se os escravos Joaquim e Tomás, que também se conservavam fugidos, tomaram parte na morte do ferreiro. Eles são citados uma única vez, num interrogatório feito a Antônio Pernambuco, e depois desapareceram da história nos autos seguintes. Afirmei então que o caso dava a impressão que a justiça não tinha o propósito de estabelecer culpas e determinar punições individuais, mas castigar exemplarmente.

De fato, o espírito do tempo era outro. A historiadora Maria Fernanda Vieira Martins, no seu premiado livro, mostrou como a relação entre as leis e a escravidão era conflituosa, feita muito mais de silêncios, negaças e tergiversações, do que de enunciados claros e razões precisas. O tempo era o da justiça dos senhores. Isso fica muito evidente nas palavras abaixo de Joaquim Nabuco.

Na história da escravidão ver-se-á que os júris de senhores primeiro condenavam sistematicamente os escravos, depois conluiavam-se para absolvê-los, em uns casos para não ser lesada a propriedade, em outros para eles serem castigados exemplarmente perante os outros escravos. Nada irritará tanto o imperador como esses conluios de jurados para substituírem a justiça pública pela dos próprios senhores. ${ }^{30}$

$\mathrm{Na}$ sociedade liberal, concebida em torno da idéia do indivíduo, o sistema judicial procura conhecer as culpas de cada um e estabelecer penas individuais. Mas, apesar dos estadistas da época saberem das virtudes do liberalismo econômico, no que diz respeito à eficácia em produzir e am- 
pliar a riqueza material, aquela era ainda, basicamente, uma sociedade do Antigo Regime e não uma sociedade liberal. Embora esse seja um assunto por demais complexo e mereça a atenção devida (mas que não cabe tratar no escopo desse artigo), escravidão e Antigo Regime mantinham ótimas relações, pois se é lícito supor que os homens não são naturalmente iguais (nem assim devem ser tratados pela lei), pode ser também que alguns sejam escravos de outros. Isso para não falar de certos princípios, caros a ambos: privilégios, deferências, respeitos, obediências. É claro que àquela altura do século o Antigo Regime já estava com os seus dias contados, todos sabiam que ele se iria tão logo fosse resolvido o "problema da mãode-obra servil”, que tantos males trazia à nacionalidade. Mas enquanto houve escravidão os costumes do Antigo Regime tiveram muita força. $\mathrm{O}$ sistema judicial daquela época é um exemplo disso. A Nabuco indignava a desenvoltura com que os poderes locais administravam a justiça de modo tão pouco republicano. Em vez de indivíduos, escravos; em vez de justiça pública (republicana), o castigo exemplar; em vez das luzes do século, as trevas do despotismo senhorial.

A sentença foi a que já se conhece pela leitura dos autos. Constantino foi absolvido e Antônio Pernambuco, Valentim e Silvestre condenados pela morte do ferreiro à pena de galés perpétuas, isto é, a trabalhos forçados sob a administração do Estado. Esses prisioneiros eram usados em obras públicas, como o calçamento de ruas, por exemplo. À primeira vista pode parecer que os réus, afinal, saíam ganhando, ao trocar João Antônio por um feitor pago pelos impostos dos contribuintes. Mas não. Valentim perdeu as roças e, se tinha família, esposa e filhos. Silvestre perdeu o galinheiro e talvez uma família, pois era compadre de Pernambuco. Esse último, além de perder coisas importantes como essas, ainda foi condenado a tomar 400 açoites na cadeia, na forma dos artigos 60 e 61 do Código Criminal. É estranho, pois o artigo 60 rezava que o réu, se fosse escravo e não incorresse nas penas de morte ou de galés, seria condenado na pena de açoites. Não era o caso, pois Pernambuco fora condenado à pena de galés perpétuas. Deve ter sido coisa da justiça dos senhores. $\mathrm{O}$ artigo 60 também estipulava que o escravo não podia tomar mais do que 50 açoites por dia. Havia de cumprir a pena, aplicá-la toda e 400 açoites de uma vez podiam matar uma pessoa. 
Sinimbu determinou que o comendador Boaventura pagasse o custo do processo, no que diz respeito aos três réus condenados, e, ato contínuo, apelou da sentença para o Tribunal da Relação, como mandava a lei. Cinco meses depois, em 29 de outubro, o tribunal exarou sentença segundo a qual não foram "inobservadas as fórmulas substanciais do processo" e dava como acertada e conforme a lei a decisão dos jurados de Nova Friburgo.

O processo acabaria aí, não fosse o último auto, de 1871, onde um desconhecido escrivão atestou o seguinte: "Certifico que os presentes autos foram encontrados neste meu cartório, na estada em que se acham, faltando neste apenso a folha em que se acha transcrito parte da sentença retro, do que dou fé. Rio de Janeiro, 21 de abril de 1871." Àquela altura onde estariam os réus? Fazia 21 anos. Valentim já devia ter morrido, pois não era mais um jovem quando do julgamento. Antônio Pernambuco e Silvestre, se vivos, já teriam por volta de 50 anos. Eram agora uns velhos. Mas isso não importa mais. Os autos conservados os fizeram perenes.

\section{Notas}

${ }^{1}$ Processo-crime número 1191, maço 185, galeria C. Vila de Nova Friburgo. O Juízo (Apelante) e Antônio Pernambuco, Silvestre Crioulo e Valentim Moçambique, Escravos de Boaventura Ferreira Maciel (Apelados). 1850. Arquivo Nacional. O processo encontra-se no Fundo Corte de Apelação.

${ }^{2}$ Embora não desenvolva nem aprofunde o problema nesse artigo, a idéia que faço hoje da escravidão está bastante influenciada pelas consideraçôes de Richard Graham, em Clientelismo e politica no Brasil do século XIX (Rio de Janeiro, Ed. UFRJ, 1997).

${ }^{3}$ MACHADO, Cacilda. A trama das vontades: negros, pardos e brancos na produção da hierarquia social (São José dos Pinhais, passagem do XVIII para o XIX). Rio de Janeiro, Universidade Federal do Rio de Janeiro, 2006. Tese de Doutoramento.

${ }^{4}$ MARQUESE, Rafael de Bivar. Feitores do corpo, missionários da mente. O ideário do governo de escravos na Américas, 1660-1860. São Paulo: Companhia das Letras, 2004.

${ }^{5}$ RUGENDAS, Johann Moritz. Viagem pitoresca através do Brasil. São Paulo, Martins; Brasília, INL, $7^{ \pm}$ed., 1976.

${ }^{6}$ Estudos sobre a alforria no Brasil têm se multiplicado nas nossas pós-graduações. Exemplo disso é a ótima tese que Marcio Soares apresentou à Universidade Federal Fluminense, em 2006. Chama-se $A$ remissão do cativeiro: alforrias e liberdades nos Campos dos Goitacazes, c. 1750 - c. 1830. As cartas que li perfazem uma série de 17.631, registradas em cartórios do Rio de Janeiro, entre 1840 e 1871. Cf. FLORENTINO, M. Al- 
forrias e etnicidade no Rio de Janeiro oitocentista: notas de pesquisa. Topoi, Revista de História. Rio de Janeiro, 2002, n. 5.

${ }^{7}$ Por exemplo: LUNA, F.V.; KLEIN, H. Evolução da sociedade e economia escravista de São Paulo, de 1750 a 1850. São Paulo: EdUSP, 2005.

${ }^{8}$ GÓES, J.R.P. Padrões de alforria no Rio de Janeiro - 1840 / 1871. In: João Fragoso et al. (org.) Nas rotas do Império. Vitória: Edufes, 2006.

${ }^{9}$ NABUCO, Joaquim. O abolicionismo. Petrópolis: Vozes, 1988, p. 102 e 103.

${ }^{10}$ VAINFAS, Ronaldo. Ideologia e escravidão: os letrados e a sociedade escravista no Brasil colonial. Rio de Janeiro: Editora Vozes, 1986.

${ }^{11}$ VAINFAS, Ronaldo. Trópico dos pecados. Rio de Janeiro: Campus, 1988.

${ }^{12}$ NABUCO, J. Op. cit., p. 12.

${ }^{13}$ LUNA e KLEIN. Op. cit. Capítulo 7.

${ }^{14}$ BETHELL, L. A abolição do comércio brasileiro de escravos. Brasília: Senado Federal, 2002.

${ }^{15}$ Cf. MANOLO, F. Op. cit., p. 16.

${ }^{16}$ KOSTER, H. Viagens ao nordeste do Brasil. Recife: Secretaria de Educação e Cultura, Governo do Estado de Pernambuco, 1978, p. 400-1.

${ }^{17}$ Achei dois casos quando estudei o livro de batismo de escravos da freguesia de Inhaúma, no Rio de Janeiro, aberto em 1816 e concluído em 1844. Cf. GÓES, J.R.P. O cativeiro imperfeito. Vitória: Lineart, 1993.

${ }^{18} \mathrm{O}$ tema foi originalmente tratado por Ciro Cardoso. Cf. CARDOSO, Ciro F.S. Escravo ou camponês? O protocampesinato negro nas Américas. São Paulo: Editora Brasiliense, 1987.

19 Como se pode constatar na página do Observatório Nacional: http://euler. on.br/cgi-bin/ephemeris/mkefem_new.pl?Year=1850\&locali=BRASILIA\&tz=$3 \&$ lon $=43 \% 3 \mathrm{~A} 12 \% 3 \mathrm{~A} 27$ \&lat $=-22 \% 3 \mathrm{~A} 54 \% 3 \mathrm{~A} 10 \& \mathrm{kal}=1171 \& \mathrm{zbj}=0 \&$ Fases $=$ Gerar

${ }^{20}$ A abolição da escravidão em Portugal ocorreu em 1761, sob o reinado de D. José I e a governança do Marquês de Pombal.

${ }^{21}$ SANT-HILAIRE, A. Segunda viagem do Rio de Janeiro a Minas Gerais e a São Paulo (1822). Col. Brasiliana, vol. 5, Companhia Editora Nacional, 1932, p. 37.

${ }^{22}$ A propósito, ver http://www.escolasempartido.org/index.php?id=38,1,article,2,13,si $\mathrm{d}, 1, \mathrm{ch}$

${ }^{23}$ Cf. GÓES, J.R.P. Escravos da paciência. Tese de doutoramento. Niterói: UFF, 1998.

${ }^{24}$ ANTONIL, A.J. Cultura e opulência do Brasil. Belo Horizonte: Ed. Itatiaia; São Paulo: Ed. Universidade de São Paulo, 1982, p. 89.

${ }^{25}$ MATTOSO, Kátia. Ser escravo no Brasil. São Paulo: Brasiliense, 1988.

${ }^{26}$ Apenas em 1871 os senhores ficaram obrigados, por lei, a vender a alforria ao escravo que pudesse pagar por ela.

${ }^{27}$ Agradeço a historiadora Maria Fernanda Vieira Martins pelas informações. 
${ }^{28}$ Lynch law. Supõe-se que a expressão nasceu da falta de escrúpulo de Charles Lynch, fazendeiro e Juiz de Paz da Virgínia, morto em 179, que desconsiderava os procedimentos legais ao perseguir opositores e inimigos.

${ }^{29}$ NABUCO, J. Op. cit., p. 39.

${ }^{30}$ NABUCO, Joaquim. Um estadista no Império. Rio de Janeiro: Topbooks, 1997, p. 234. Maria Fernanda Martins comenta o trecho em MARTINS, Fernanda M. V. A velha arte de governar: um estudo sobre politica e elites a partir do Conselho de Estado (18421889). Rio de Janeiro: Arquivo Nacional, 2007, p. 355.

\section{RESUMO}

$O$ artigo analisa os arquivos de uma ação penal que foi realizado na vila de Nova Friburgo, provincia do Rio de Janeiro, em 1850. Os réus eram escravos na fazenda que pertencia ao Comendador Boaventura Ferreira Maciel, a Fazenda Ponte das Tábuas. Eles foram acusados de matar o ferreiro da fazenda, em uma noite escura e chuvosa, no dia 13 de fevereiro, do mesmo ano. Nos arquivos, há depoimentos interessantes quanto à vida dos escravos no Sudeste do Brasil em meados do século 19. Palavras-chave: escravidão, Rio de Janeiro, ação penal, justiça, Império do Brasil.

\section{ABSTRACT}

The article examines the files of a criminal lawsuit that was carried out in the village of Nova Friburgo, province of Rio de Janeiro, in 1850. The defendants were slaves in the farm that belonged to the commendatary Boaventura Ferreira Maciel, the Fazenda Ponte das Tábuas. They were accused of killing the farm's blacksmith, in the dark and rainy night of February the 13th, in that year. In the files there are interesting testimonies regarding the lives of slaves in the Southeast of Brazil in the middle 19th century.

Keywords: slavery, Rio de Janeiro, criminal lawsuit, justice, Empire of Brazil.

Recebido em janeiro de 2008 e aprovado em maio de 2008 